\title{
a4-integrins control viral meningoencephalitis through differential recruitment of T helper cell subsets
}

\author{
Veit Rothhammer ${ }^{1 \dagger}$, Andreas Muschaweckh ${ }^{2 \dagger}$, Georg Gasteiger ${ }^{3}$, Franziska Petermann ${ }^{1}$, Sylvia Heink, \\ Dirk H Busch ${ }^{4}$, Mathias Heikenwälder ${ }^{2}$, Bernhard Hemmer ${ }^{1,5}$, Ingo Drexler ${ }^{6}$ and Thomas Korn ${ }^{1,5^{*}}$
}

\begin{abstract}
Introduction: Natalizumab blocks a4-integrins and is a prototypic agent for a series of anti-inflammatory drugs that impair trafficking of immune cells into the CNS. However, modulation of the access of immune cells to the CNS is associated with impaired immune surveillance and detrimental viral infections of the CNS. Here, we explored the potency of cellular immune responses within the CNS to protect against viral encephalitis in mice with T cell conditional disruption of VLA-4 integrin (a4ß1) expression.

Results: While VLA-4 expression in virus specific Th1 cells is non-redundant for their ability to access the CNS, a4-integrin deficient Th17 cells enter the CNS compartment and generate an inflammatory milieu upon intrathecal vaccinia virus (W) infection. However, in contrast to Th1 cells that can adopt direct cytotoxic properties, Th17 cells fail to clear the virus due to insufficient Eomes induced perforin-1 expression.

Conclusion: The quality of the intrathecal cellular antiviral response under conditions of impaired VLA-4 function jeopardizes host protection. Our functional in vivo data extend our mechanistic understanding of anti-viral immunity in the CNS and help to estimate the risk potential of upcoming therapeutic agents that target the trafficking of immune cells into distinct anatomical compartments.
\end{abstract}

\section{Introduction}

Autoimmune inflammation of the CNS in multiple sclerosis (MS) and its animal model, experimental autoimmune encephalomyelitis (EAE), is mediated by antigen specific Th1 and Th17 cells [1]. For many years integrin targeted blocking of $\mathrm{T}$ helper cell trafficking into the CNS has appeared to be an attractive approach to treat immunopathology in MS [2]. In particular, monoclonal antibodies (natalizumab) to the $\alpha 4$ subunit of the integrin VLA-4 ( $\alpha 4 \beta 1$ heterodimer) were successfully used to prevent the influx of immune cells into the CNS and to treat CNS autoimmunity [3]. However, in experimental models it has been shown that distinct encephalitogenic $\mathrm{T}$ cell subsets vary in their equipment with VLA-4 [4].

\footnotetext{
* Correspondence: korn@|rz.tum.de

${ }^{\dagger}$ Equal contributors

'Klinikum rechts der Isar, Department of Neurology, Technische Universität München, Ismaninger Str. 22, 81675 Munich, Germany

${ }^{5}$ Munich Cluster for Systems Neurology (SyNergy), Munich, Germany

Full list of author information is available at the end of the article
}

While Th1 cells maintain high amounts of VLA-4 expression, Th17 cells are low in VLA-4. As a consequence, blockade of VLA-4 is more efficient in preventing the recruitment of Th1 cells than of Th17 cells into the CNS parenchyma.

Although considered as an "immune privileged" organ, the CNS is still patrolled by T cells as a means of immune surveillance [5]. The contribution of $\mathrm{CD}^{+}$vs $\mathrm{CD} 8^{+}$ effector memory $\mathrm{T}$ cells in the migratory and resident pools of lymphocytes specific to a given pathogen has been investigated in skin infection but is unclear in the CNS [6]. In the treatment of organ specific autoimmunity and chronic inflammation, efforts are increasing to market compounds that either inhibit immune cell trafficking [7-10] or cytokine networks that affect distinct $\mathrm{T}$ helper cell subsets in a differential manner (anti-IL-23p19, antiIL-17A [11,12], anti-GM-CSF (NCT01517282), anti-IL-6R [13]). However, preclinical models to investigate niche specific immune surveillance and host defense in the CNS are rare. Indeed, efalizumab, a blocking antibody to the 
integrin $\alpha \mathrm{L}$ was withdrawn from the market in 2009 because of viral meningitis and cases of JC virus induced progressive multifocal leukencephalopathy (PML) [14].

Here, we established a CNS specific viral infection model that allowed us to analyze the contribution of distinct $\mathrm{T}$ helper cell subsets to host protection. We chose vaccinia virus (VV) infection where the importance of virus specific $\mathrm{T}$ helper cell responses has been analyzed previously $[15,16]$. Vaccinated mice were found to be protected from intrathecal (i.th.) infection with VV due to cellular immunity. In the absence of $\mathrm{CD}^{+} \mathrm{T}$ cells, Th1 like cells were sufficient to protect mice from intrathecal VV infection. Access of Th1 cells into the infected CNS compartment was dependent on VLA-4 expression. Although virus specific Th17 cells were able to migrate into the CNS in the absence of VLA-4, CNS recruited and infected macrophages were not cleared by Th17 cells since Th17 cells - in contrast to Th1 cells - were deficient in perforin-1 expression. These data highlight a dominant role of Th1 cells in antiviral tissue-specific immunity. Our data further suggest that as in autoimmune inflammation of the CNS, virus specific Th1 cells are dependent on VLA-4 to enter into the CNS and virus infection does not overcome the requirement for Th1 cells to express VLA-4. Thus, integrin targeted therapeutic interventions in autoimmunity and chronic inflammation need to be refined in order to not jeopardize organ specific immune surveillance and host protection.

\section{Materials and methods}

\section{Animals, immunization, and infection}

Foxp3gfp.KI mice [17,18] and Itga $4^{\text {flox/flox }}$ mice [19] have been described previously. CD4 Cre mice, Ifng ${ }^{-/-}$mice, $\mathrm{Ragl}^{-/-}$mice, $\mathrm{Prf1}^{-/-}$mice, and wild type C57BL/6 mice were obtained from Jackson Laboratories. CD45.1 ${ }^{+}$OT-II mice were kindly provided by DH Busch (Institute for Medical Microbiology, Immunology, and Hygiene, Technische Universität München). All mouse strains were on pure C57BL/6 background.

Mice were immunized by subcutaneous injection of $100 \mu \mathrm{l}$ of an emulsion of $1 \times 10^{8}$ IU MVA or PBS in complete Freund's adjuvant (CFA). For in vivo blockade of IFN- $\gamma$, mice were treated with every other day i.p. injections of a neutralizing antibody to IFN- $\gamma$ (R4-6A2, BioXCell, West Lebanon, USA; $200 \mu \mathrm{g}$ ) or isotype control starting on day 9 after immunization. In a similar regimen, blocking antibodies to integrin $\alpha 4$ (PS/2, BioXCell, West Lebanon, USA; $200 \mu \mathrm{g}$ ), depleting antibodies to CD8 (YTS169.4, BioXcell; $200 \mu \mathrm{g}$ ) or CD4 (GK1.5, BioXcell; $200 \mu \mathrm{g}$ ) were administered every other day from day 9 or day 10 after immunization, respectively.

Intrathecal infection was performed as previously described [20]. In brief, VV was inoculated into the cisterna magna of mice in deep anaesthesia by means of transcutaneous suboccipital puncture. Clinical signs of disease as well as weight loss in percent of initial weight (means + SEM) were monitored daily.

For adoptive transfer experiments, naïve $\mathrm{T}$ cells were isolated by magnetic sorting $\left(\mathrm{CD}^{+} \mathrm{CD}^{+} 2 \mathrm{~L}^{+}\right.$; $\mathrm{T}$ cell isolation kit II, mouse; Miltenyi Biotec, Germany) from CD 45.1 $1^{+}$OT-II mice and differentiated in vitro into Th1 or Th17 cells. The differentiation status was checked on day 4 by intracellular cytokine staining and $2 \times 10^{6}$ cytokine positive $\mathrm{T}$ cells were injected i.v. into $\mathrm{Rag}^{-1-}$ recipient mice, which had been infected with VV-Ova one day prior to $\mathrm{T}$ cell transfer.

Animals were kept in a specific pathogen-free facility at the Technische Universität München. All experimental protocols were approved by the standing committee for experimentation with laboratory animals of the Bavarian state authorities ("Governmental Department of Upper Bavaria, Approved animal experimental proposals No 55.2-1-54-2531-88-08 and No 55.2.1-54-253229-13 according to $\$ 8.1$, German law for experimentation with laboratory animals") and carried out in accordance with the corresponding guidelines.

\section{Virus strains}

Replication competent VV Western Reserve strain (VV) was provided by B Moss (National Institutes of Health, Bethesda, MD). Recombinant viruses encoding enhanced green fluorescent protein (VV eGFP) or fulllength ovalbumin (VV-Ova) based on the Western Reserve strain were provided by JW Jewdell and JR Bennink (National Institutes of Health, Bethesda, MD). VV and replication deficient Modified Vaccinia Virus Ankara strain (MVA, cloned isolate IInew) used in this study were propagated and titered according to standard methodology [21].

\section{$T$ cell differentiation}

Naïve T cells $\left(\mathrm{CD} 4^{+} \mathrm{CD} 62 \mathrm{~L}^{\text {high }} \mathrm{CD} 25^{-}\right)$were isolated from lymph nodes and spleen by magnetic sorting ( $\mathrm{T}$ cell isolation kit II, mouse; Miltenyi Biotec, Germany). Purity was in general higher than $95 \%$ as controlled by FACS staining. Naïve T cells were stimulated for 3 to 5 days with plate-bound antibody to CD3 $(145-2 \mathrm{C} 11,4 \mu \mathrm{g} / \mathrm{ml})$ and antibody to CD28 (PV-1, $2 \mu \mathrm{g} / \mathrm{ml})$. Recombinant cytokines were added to the differentiation cultures as indicated: human TGF- $\beta 1$ ( $2 \mathrm{ng} / \mathrm{ml})$ and mouse IL-6 (50 ng/ml) for Th17, mouse IL-12 (10 ng/ml) and antiIL-4 $(10 \mu \mathrm{g} / \mathrm{ml})$ for Th1, all R\&D Systems.

\section{Preparation of splenic and CNS mononuclear cells and antibody staining}

Mononuclear cells were isolated from either spleen or $\mathrm{CNS}$ at the peak of disease (d4-d5 after intrathecal 
challenge). After perfusion through the left cardiac ventricle with cold PBS, the brain including cerebellum was dissected and the spinal cord flushed out with PBS by hydrostatic pressure. CNS tissue was digested with collagenase D $(2.5 \mathrm{mg} / \mathrm{ml}$, Roche Diagnostics, Indianapolis IN) and DNAseI ( $1 \mathrm{mg} / \mathrm{ml}$, Sigma, Saint Louis, MO) at $37^{\circ} \mathrm{C}$ for $45 \mathrm{~min}$. Mononuclear cells were isolated by passing the tissue through a cell strainer $(70 \mu \mathrm{m})$ and percoll gradient (37\% over $70 \%)$ centrifugation. Mononuclear cells were removed from the interphase, washed and resuspended in culture medium for further analysis. For isolation of mononuclear cells from spleen, spleens were mashed through a cell strainer $(70 \mu \mathrm{m})$ and red blood cells were removed using BD Pharm Lyse (BD Biosciences). Surface staining of T cells was carried out with antibodies to CD3 (14-2C11), CD4 (RM4-5), CD8 (53-6.7), CD11b (M1/70), CD25 (PC61 or 7D4), CD44 (IM7), CD45 (30-F11) and Nk1.1 (PK136). All antibodies were purchased from $\mathrm{BD}$ Biosciences. Fluorescencelabeled MHC class I $\mathrm{H}-2 \mathrm{~K}^{\mathrm{b}} / \mathrm{B}^{2} \mathrm{R}_{20-27}$ (TSYKFESV) multimers were provided by DH Busch.

\section{Intracellular cytokine staining}

Cells were stimulated in culture medium containing phorbol 12-myristate 13-acetate (PMA, $50 \mathrm{ng} / \mathrm{ml}$, Sigma), ionomycin $(1 \mu \mathrm{g} / \mathrm{ml}$, Sigma), and monensin (GolgiStop $1 \mu \mathrm{l} / \mathrm{ml}, \mathrm{BD}$ Biosciences) at $37^{\circ} \mathrm{C}$ and $10 \% \mathrm{CO}_{2}$ for 4 hours. After staining of surface markers, cells were fixed and permeabilized (Cytofix/Cytoperm and Perm/ Wash buffer, BD Biosciences) followed by staining with monoclonal antibodies to mouse IL-2, IL-17, or IFN- $\gamma$ (BD Biosciences) and flow cytometric analysis (CYAN, Beckmann/Coulter).

\section{Histologic analysis}

For detection of VV-infected cells or macrophages, paraformaldehyde (PFA) (4\%) fixed and paraffin embedded CNS tissue sections were incubated with Bond Primary Antibody Diluent (Leica) containing either polyclonal rabbit anti-VV serum (1:1000; Quartett Immunodiagnostika \& Vertriebs-GmbH, Berlin) or monoclonal antibodies against Mac-3 (1:750; M3/84) purchased from BD Pharmingen. IHC staining was performed on an automated Leica BOND-MAX instrument using Bond Polymer Refine Detection Solution for DAB. For detection of GFAP, PFA-fixed and paraffin-embedded CNS sections were incubated with Dako polyclonal rabbit anti-GFAP antibodies (Z0034; 1:13000) in Ventana buffer and staining was performed on a Ventana NexES IHC Slide Stainer using iVIEW DAB Detection Kit (Ventana). Images were taken using the Leica SCN400 slide scanner analysis software or were acquired on an Olympus BX53 Microscope (DP72 camera) using the cellSens 1.8 digital imaging software (Olympus).

\section{Quantitative PCR analysis}

For quantitative PCR, RNA was extracted from magnetic bead-purified or flow cytometry-sorted cells ex vivo or after in vitro differentiation using RNeasy columns (Qiagen, Valencia, CA). Complementary DNA was transcribed as recommended (Applied Biosystems, Foster City, CA) and used as template for quantitative PCR. Primer plus probe mixtures were obtained from Applied Biosystems. The Taqman analysis was performed on a StepOne system from Applied Biosystems. The gene expression was normalized to the expression of $\beta$-actin.

\section{Western blotting}

$\mathrm{T}$ cells were lysed and denatured using RiPA buffer (Sigma-Aldrich). The protein lysates were separated by SDS-PAGE in $4-12 \%$ NuPAGE Bis-Tris Mini gels and transferred to nitrocellulose membranes (Invitrogen). After blocking with 5\% low-fat dry milk in TBS-T, membranes were incubated with primary antibodies to Prf-1 (ab7203, Abcam) and $\beta$-actin (Abcam) in blocking solution overnight at $4^{\circ} \mathrm{C}$. Primary antibody binding was detected with HRP-conjugated secondary antibodies (Dianova). The signal was visualized by enhanced chemiluminescence (Novex ECL, Invitrogen).

\section{Antigen specific proliferative and cytokine responses}

For CD154 (CD40L) staining, spleens from MVA immunized CD4 Cre- $\times$ Itga $4^{f l o x / f l o x}$ or CD4 $\mathrm{Cr}^{+} \times$Itga $^{\text {flox/flox }}$ mice were dissected on day 10 after immunization. Single cell suspensions were prepared and cells were seeded on a 12 well flat-bottom plate at a density of $2 \times 10^{6}$ cells/well. Single cells were restimulated with a mixture of I-A $\mathrm{A}^{\mathrm{b}}$-restricted $\mathrm{VV}$ peptides (A33R, B2R, B5R, L4R; $30 \mu \mathrm{g} / \mathrm{ml}$ each) for 6 hours in the presence of brefeldin A $(5 \mu \mathrm{g} / \mathrm{ml})$ during the last 3 hours of incubation followed by surface and intracellular staining for CD40L (CD154 (MR1), eBioscience) and cytokines as indicated. A33R $116-130$ (YQLFSDAKANCTAES), B2R 46-60 (VKDKYMWCYSQ VNKR), B5R $46-60$ (FTCDQGYHSSDPNAV) and L4R $_{176-190}$ (ISKYAGINILNVYSP) were obtained from Biosyntan, Berlin.

\section{Retroviral transduction of T cells}

pMIG Eomes (GFP) and control pMIG (GFP) retroviral constructs were a kind gift from SL Reiner (University of Pennsylvania, Philadelphia, PA) and FJ Quintana (Harvard Medical School, Boston, MA). Phoenix-Eco cells (PMID: 18432682, a kind gift of H-M Jaeck, Erlangen) were transiently transfected with plasmids by calcium phosphate precipitation in the presence of $25 \mu \mathrm{M}$ chloroquine (Sigma Aldrich). Retroviral supernatants were collected two days post transfection. T cells were transduced 24 hours post polyclonal in vitro activation of naïve sorted $\mathrm{CD} 4^{+} \mathrm{T}$ cells with TGF- $\beta$ and IL-6 (Th17). Retroviral supernatant and 
$4 \mu \mathrm{g} / \mathrm{ml}$ polybrene (Merck Millipore) were added to the pre-committed Th17 cells and a spin transduction was performed (2000 rpm, RT, 1 hour). Cells were further cultured for 3 days in Th17 polarizing conditions before GFP expressing cells were purified by FACS sorting and subjected to quantitative PCR analysis.

\section{Plaque assay}

CNS tissue was digested as described and single cell suspensions were obtained by passing digested CNS tissue through a $70-\mu \mathrm{m}$ nylon filter. Pelleted cells were subjected to three freeze-thaw cycles $\left(-80^{\circ} \mathrm{C}\right.$ and $\left.37^{\circ} \mathrm{C}\right)$ and sonicated three times for $1 \mathrm{~min}$. Serial dilutions in RPMI-1640 medium containing 10\% FCS were added in duplicates to $90 \%$ confluent RK-13 cells seeded in 6-well plates and incubated for 24 hours at $37^{\circ} \mathrm{C}$. Plaques were counted after crystal violet staining.

\section{Neutralization assay}

Mouse serum samples were collected at day 10 post immunization (MVA/CFA or PBS/CFA). All serum samples were heat-inactivated at $56^{\circ} \mathrm{C}$ for $30 \mathrm{~min}$ prior to testing. Serum dilutions were incubated with 10,000 PFU of sucrose gradient purified VV eGFP for 1 hour at $37^{\circ} \mathrm{C}$ and $5 \% \mathrm{CO}_{2}$ in a 96-well plate. RK-13 cells were added and infection $(\mathrm{MOI}=0.1)$ was carried out over night at $37^{\circ} \mathrm{C}$ and $5 \% \mathrm{CO}_{2}$. Cells were harvested, washed and fixed in $1 \%$ paraformaldehyde. Percentage of VV-infected cells was determined by measuring eGFP expression in flow cytometric analyses (CYAN, Beckmann/ Coulter). The percentage of virus neutralization was defined as (1-[percentage of GFP-expressing cells]/ [percentage of GFP-expressing cells in controls without serum]) $\times 100$.

\section{Statistical analysis}

Statistical evaluations of cell frequency measurements and gene expression levels were performed with the unpaired Student's t test. Two-tailed $\mathrm{p}$ values $<0.05$ were considered significant. Weight scores are given as means \pm SEM. Multiple comparisons were performed by two-way-ANOVA and Bonferroni post-testing.

\section{Results}

\section{Intrathecal vaccinia virus (VV) infection causes lethal encephalitis}

To establish a model of viral encephalitis, female C57BL/6 mice were injected intrathecally with $\mathrm{VV}$ by suboccipital puncture of the cisterna magna. By titrating the dose of the inoculum, the half lethal dose (LD50) was determined to be approximately 500 plaque forming units (PFU) (Figure 1A). In systemic infection, VV is known to preferentially replicate in the ovaries upon hematogenous dissemination. We therefore measured viral loads in
CNS and ovaries of mice injected i.th. with 1.000 PFUs of VV. While high titers of VV were measured in the CNS, virus was not detected in the ovaries of intrathecally infected mice (Figure 1B) indicating that intrathecal injection of $\mathrm{VV}$ led to a compartmentalized infection within the CNS without systemic dissemination. Within the CNS compartment, VV antigen was detected in ventricular lining cells and plexus epithelium cells as well as in astrocytes of the glia limitans. Some innate immune cells of monocytic origin that were recruited to the infected CNS compartment were also positive for VV antigen (Figure 1C).

In order to determine immune cell targets of $\mathrm{VV}$ within the CNS, we infected wild type mice with recombinant VV expressing enhanced green fluorescent protein (VV eGFP). When analyzing eGFP expression in distinct cell populations of the CNS on day 4 after infection, we found a sizable fraction of eGFP expressing cells only within the $\mathrm{CD} 11 \mathrm{~b}^{\text {high }} \mathrm{CD} 45^{\text {high }}$ macrophage compartment (Figure 2). This is in line with a recent study which identified infiltrating $\mathrm{CD} 11 \mathrm{~b}^{+} \mathrm{CD} 45^{+}$inflammatory monocytes as the predominant $\mathrm{VV}$ infected leukocyte population during VV skin infection [22]. Microglial cells $\left(\mathrm{CD} 11 \mathrm{~b}^{+} \mathrm{CD} 45^{\text {low }}\right)$, $\mathrm{T}$ cells and $\mathrm{B}$ cells did not show eGFP expression. In addition, we were unable to detect eGFP expressing cells in the spleens of intrathecally injected mice, further demonstrating that $\mathrm{VV}$ infection was restricted to the CNS compartment. Importantly,

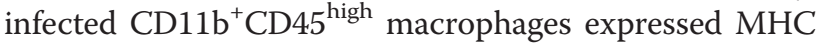
class II (Figure 2B). Thus, phagocytic cells were recruited from the systemic compartment in response to i.th. VV infection and became targets of virus replication but were unable to control the infection (see Figure 1A).

\section{Immunization with modified vaccinia virus (MVA) protects against VV encephalitis}

As macrophages became infected during VV encephalitis but failed to eliminate the virus, we hypothesized that adaptive cellular immune responses were required for virus control. In order to investigate the contribution of antigen specific effector $\mathrm{T}$ helper cells to host defense against i.th. VV infection, we immunized wild type mice with a replication deficient strain of VV (MVA) emulsified in complete Freund's adjuvant (CFA) 10 days prior to i.th. challenge with VV. CFA induces both Th1 and Th17 responses. Here, we were interested in investigating the role of these $\mathrm{T}$ helper cell subsets in the trade-off between host protection and immunopathology during infectious encephalitis. While sham-immunized mice died at day 6 after infection and largely failed to recruit either $\mathrm{CD}^{+}{ }^{+} \mathrm{T}$ helper cells or VV-specific CTLs into the CNS compartment (Figure 3A,B), MVA immunized animals harbored both antigen specific CTLs and CD4 ${ }^{+} \mathrm{T}$ cells in the CNS and recovered from VV encephalitis 

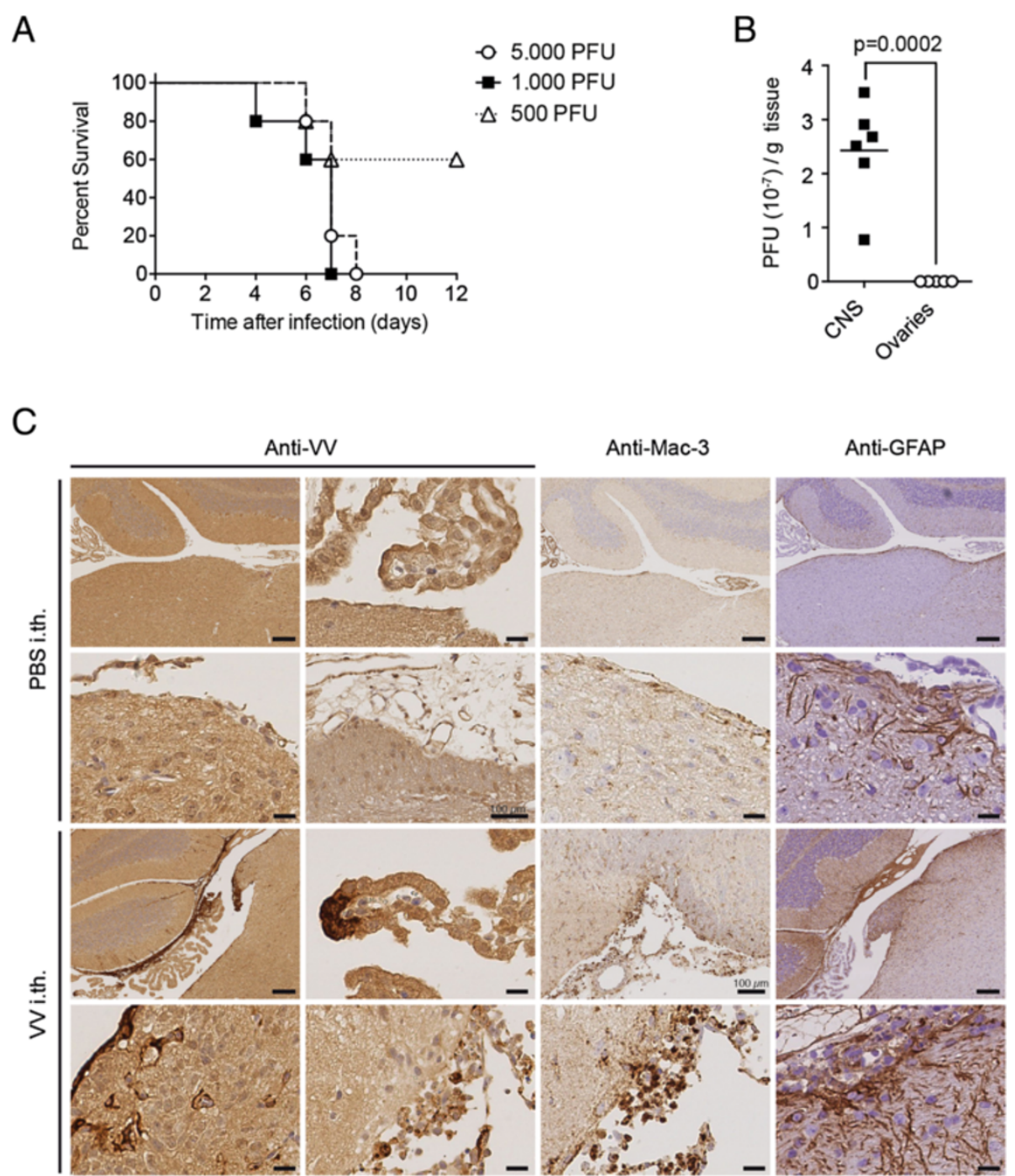

Figure 1 Intrathecal infection with VV causes lethal encephalitis. (A) C57BL/6 wild type mice were injected intrathecally by suboccipital puncture of the cisterna magna with various doses of W. Percentage of surviving mice are depicted in Kaplan-Meier curves ( $n=5$ per group). (B) Virus loads in CNS and ovaries of wild type mice infected intrathecally with W were measured on day 5 after infection (Student's $t$ test, $\mathrm{n} \geq 5$ ). (C) Wild type mice injected with $W$ were subjected to histologic analyses on day 5 after infection. Unless otherwise indicated, scale bars represent $200 \mu \mathrm{m}$ in the low magnification and $20 \mu \mathrm{m}$ in the higher magnification photomicrographs.

(Figure 3A-C). While CTLs re-isolated from the CNS largely produced IFN- $\gamma$, the intrathecal $\mathrm{CD} 4^{+}$effector T cell compartment comprised IFN- $\gamma$ producers, IL-17 producers, and IFN- $\gamma / \mathrm{IL}-17$ double producers (Figure 3C). In summary, protective immunity against intrathecal VV infection was associated with the mobilization of both CTLs and $\mathrm{CD} 4^{+}$effector $\mathrm{T}$ helper cells to the CNS.

\section{Antibody mediated blockade of a4-integrins leads to relative enrichment of Th17 cells in the CNS}

We next wished to dissect the specific contribution of different $\mathrm{T}$ cell subsets to the protective effects of vaccination. Here, we took advantage of the differential integrin requirement for the recruitment of Th1 cells vs
Th17 cells into the CNS compartment. In the EAE model, Th1 cells depend on $\alpha 4$-integrins in order to enter into the CNS during autoimmune inflammation. In contrast, Th17 cells are able to access the CNS compartment independently of $\alpha 4$-integrins using an LFA-1 dependent mechanism [4]. Here, we treated our MVA immunized mice with blocking antibodies to integrin $\alpha 4$ (PS/2) prior to i.th. VV challenge (Figure 4A). Notably, MVA immune mice survived i.th. VV infection in spite of integrin $\alpha 4$ blockade (Figure 4A). As expected, we found a relative abundance of IL-17 producing T cells as compared with IFN- $\gamma$ positive T helper cells (Figure 4B). This finding supported the idea that - similar to $\mathrm{T}$ cell recruitment in autoimmune inflammation of the 
A

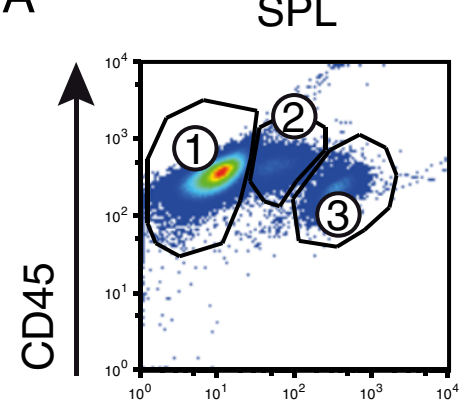

CD11b

B

SPL

(1)

(2)

(3)

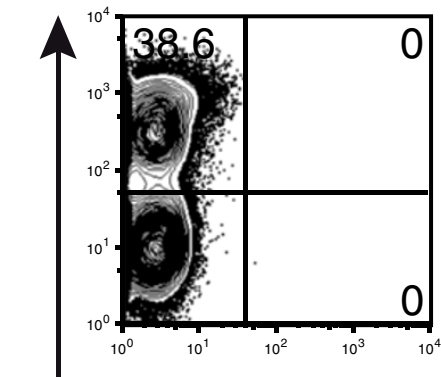

(3)
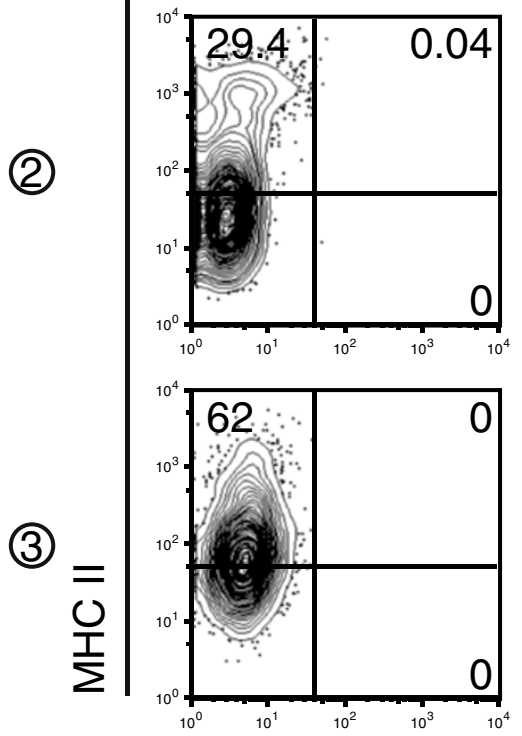

VV (eGFP)
CNS

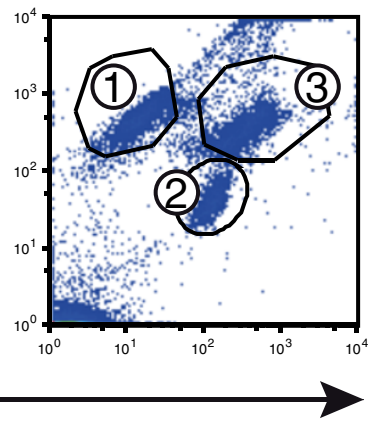

CNS
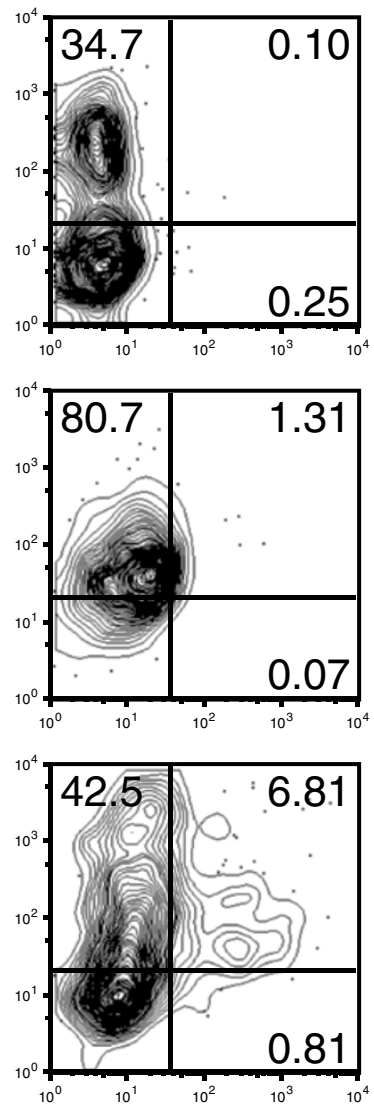

Figure $\mathbf{2}$ MHC class II positive macrophages are targets of VV infection in the CNS. Wild type mice were infected intrathecally with 1.000 PFUs of W (eGFP), a replication competent recombinant W expressing enhanced green fluorescent protein (eGFP) in infected cells. On day 4 after infection, mice were sacrificed, and spleen and CNS mononuclear cells were isolated and analyzed by flow cytometry. In the live cell gate, the following populations were defined based on their expression of CD11b and CD45: (A) spleen (SPL), left panel: (1) CD11 b ${ }^{\text {low } C D 45^{\text {high }}}$

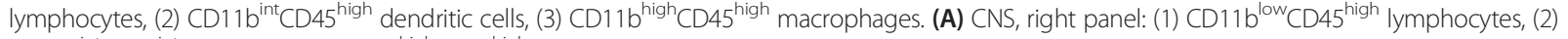
CD11 $b^{\text {int }} C D 45^{\text {int }}$ microglia, (3) CD11 $b^{\text {high }} C D 45^{\text {high }}$ macrophages. (B) These populations were analyzed as to their expression of eGFP and MHC class $\|$ by flow cytometry. Numbers indicate percentages of positive cells in each quadrant or gate (representative out of 3 independent experiments). 
CNS - Th1 cells and Th17 cells exhibited distinct integrin requirements for their entry into CNS in the context of a local virus infection. Interestingly, while the absolute number of $\mathrm{CD} 4^{+} \mathrm{T}$ cells was reduced in the CNS, which was largely due to the reduction of IFN- $\gamma$ producing $\mathrm{CD}^{+}$effector $\mathrm{T}$ cells, the number of CTLs recruited to the CNS compartment was not significantly reduced in anti-integrin $\alpha 4$ treated mice (Figure $4 \mathrm{C}$ ). Thus, integrin $\alpha 4$ mediated mechanisms appeared to be redundant for the recruitment of effector $\mathrm{CD}^{+} \mathrm{T}$ cells into the infected CNS.

\section{Th17 cells fail to clear cerebral VV infection}

Similar to the murine system, neutralization of $\alpha 4$ integrins by natalizumab in humans mainly blocks $\mathrm{CD}^{+} \mathrm{T}$ cells from entering into the CNS compartment but spares $\mathrm{CD}^{+} \mathrm{T}$ cells $[23,24]$. Yet, intracerebral reconstitution of $\mathrm{CD}^{+}$effector $\mathrm{T}$ helper cell responses has been proposed to be necessary for efficient clearance of various viruses from the CNS including JC virus [25]. We wanted to dissect the essential features of an intracerebral $\mathrm{T}$ helper cell response that would be able to control viral infection. Thus, we combined a system of $\mathrm{T}$ cell conditional ablation of $\alpha 4$-integrin expression (CD4 Cre $\mathrm{Cr}^{+} \times$Itgaf $^{\text {flox/flox }}$ mice, $\alpha 4$ CKO mice) with antibody mediated depletion of $\mathrm{CD}^{+} \mathrm{T}$ cells in order to investigate the differential contribution of Th1 cells vs Th17 cells to host protection in CNS infection in the absence of CTLs. To exclude possible alterations in priming of antigen specific $\mathrm{T}$ helper cell responses in the peripheral immune compartment of $\alpha 4 \mathrm{CKO}$ mice, we compared the fractions of antigen specific $\mathrm{T}$ cells on day 10 after subcutaneous immunization with MVA/CFA in the spleens of CD4 Cre $x$ Itgafflox/flox (wild type control) versus CD4 Cre $\mathrm{Cr}^{+}$Itga4 $4^{\text {flox/flox }}$ ( $\alpha 4$ $\mathrm{CKO}$ ) mice (Additional file 1: Figure S1). Upon ex vivo restimulation with $\mathrm{I}-\mathrm{A}^{\mathrm{b}}$ restricted $\mathrm{VV}$ epitopes, the fractions of antigen specific $\left(\mathrm{CD} 40 \mathrm{~L}^{+}\right) \mathrm{CD}^{+} \mathrm{T}$ cells and their cytokine profile were similar in wild type vs $\alpha 4$ CKO mice. Moreover, the anti-VV neutralizing serum response was equally effective in both groups on day 10 after immunization (Additional file 1: Figure S1). Thus, sensitization for adaptive cellular immune responses against VV in draining lymph nodes and spleen was not impaired by the lack of $\alpha 4$-integrins on $\mathrm{T}$ cells.

Next, we challenged MVA immune and $\mathrm{CD}^{+}$depleted wild type and $\alpha 4 \mathrm{CKO}$ mice with i.th. VV. In contrast to control littermates, $\alpha 4$ CKO mice rapidly lost weight and succumbed to infection (Figure 5A). Even in the complete absence of $\mathrm{CD}^{+} \mathrm{T}$ cells (Figure $5 \mathrm{~B}$ ), $\mathrm{CD} 4^{+}$effector $\mathrm{T}$ helper cells were protective in wild type mice but failed to control virus replication in the CNS of $\alpha 4$ $\mathrm{CKO}$ mice (Figure 5C). Recapitulating our observations with anti- $\alpha 4$ integrin (PS/2) administration, $\alpha 4$-integrin deficient $\mathrm{T}$ helper cells re-isolated from the CNS of VV challenged mice exhibited a Th17 like phenotype while the number of Th1 like cells was significantly reduced in $\alpha 4$ CKO animals as compared with controls (Figure 5D, E). Consistent with their cytokine production upon ex vivo stimulation, CNS derived $\alpha 4$-integrin deficient $\mathrm{T}$ helper cells expressed higher amounts of Th17 signature markers such as Rorc, Il17, Il22, Il6, Ccr6, or Il1r1 whereas Th1 associated genes like Cxcr3, Ccr5, or Ccr 2 prevailed in wild type $\mathrm{T}$ helper cells (Figure 5F). In conclusion, while Th1 cells appeared to be sufficient to provide host protection in intrathecal VV infection, Th17 cells failed to control cerebral virus replication in the absence of $\mathrm{CD}^{+} \mathrm{T}$ cells resulting in lethal encephalitis.

To corroborate that Th1 immunity was sufficient to improve the outcome of intrathecal viral infection, we established a model of adoptively transferred host protection using OT-II T cells, which carry a transgenic $\mathrm{T}$ cell receptor specific to ovalbumin, in combination with a recombinant VV expressing ovalbumin in infected cells (VV-Ova). Naive OT-II cells were differentiated in vitro into Th1 cells or Th17 cells followed by transfer into $\mathrm{Rag1}^{-/-}$mice, which had been infected intrathecally with VV-Ova one day prior to adoptive transfer (Figure 6). While non-transferred Rag1 deficient recipients and recipients of Th17 cells rapidly died, Th1 recipients survived significantly longer than their counterparts (Figure 6A). Despite a significant difference in clinical outcome, equal amounts of transferred Th1 cells and Th17 cells were reisolated from the CNS of infected mice (Figure 6B). Thus, on a per cell basis, antigen specific Th1 cells appeared to be more potent in alleviating i.th. virus infection than antigen specific Th17 cells.

\section{Th17 cells fail to clear i.th. VV infection due to lack of perforin-1 expression}

It was possible that the reduced capacity of Th17 cells to provide host protection in intrathecal VV infection was simply due to reduced availability of IFN- $\gamma$ within the CNS compartment. In order to test this possibility, we neutralized IFN- $\gamma$ by monoclonal antibodies in MVA immune and $\mathrm{CD}^{+} \mathrm{T}$ cell depleted wild type mice (Additional file 2: Figure S2). In this purely $\mathrm{T}$ helper cell dependent scenario, VV specific Th1 and Th17 cells were generated and had access to the $\mathrm{VV}$ challenged CNS. Notably, the mice recovered from VV encephalitis despite ablation of IFN- $\gamma$. Efficiency of IFN- $\gamma$ blockade was documented by reduced levels of MHC class II expression on microglial cells in the CNS compartment (Additional file 2: Figure S2). These data suggested that IFN- $\gamma$ was redundant as an effector molecule in the clearance of intrathecal VV infection and refuted the idea that diminished IFN- $\gamma$ expression by Th17 cells 


\section{A}
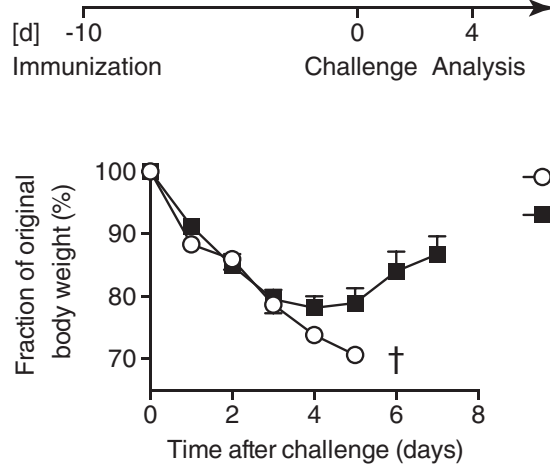

- - PBS/CFA

$\rightarrow-$ MVA/CFA

B
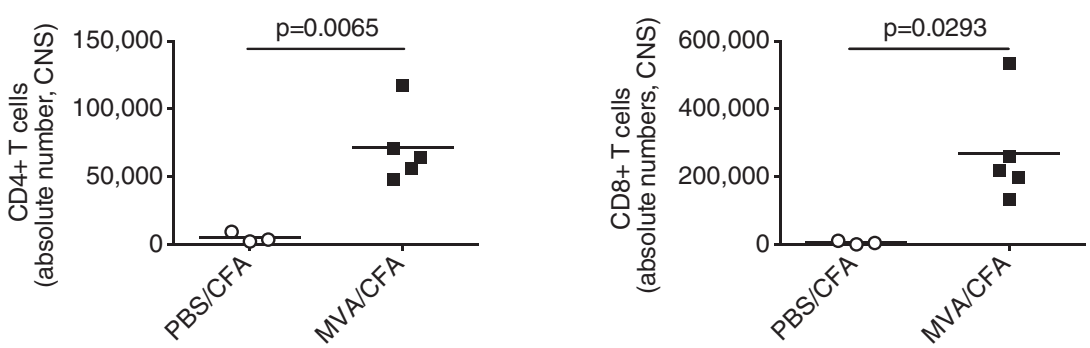

C

PBS/CFA

MVA/CFA

CD8+ T cells
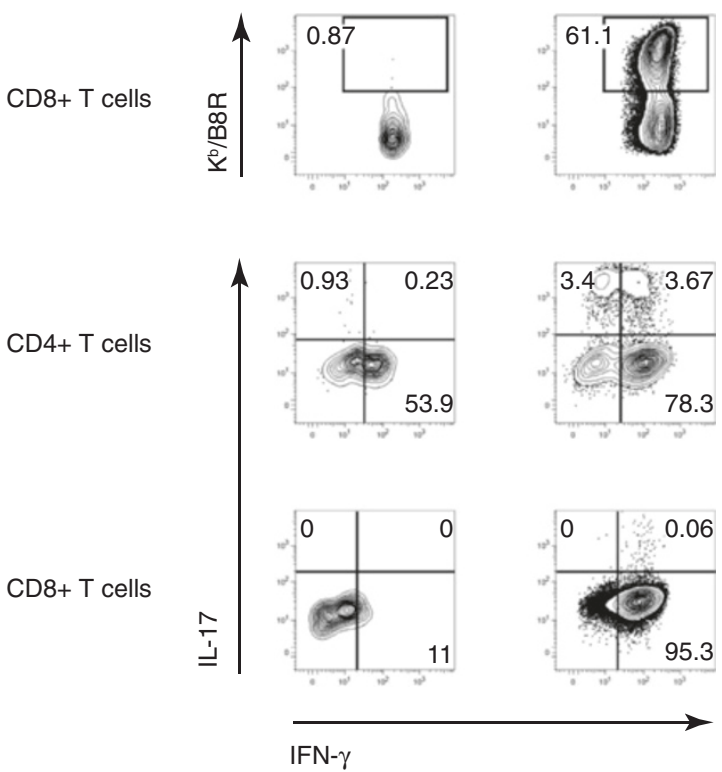

Figure 3 Immunization with modified VV Ankara (MVA) confers protective immunity against viral encephalitis. Wild type mice were immunized subcutaneously with a replication deficient strain of W (Modified Vaccinia Virus Ankara, MVA) or PBS emulsified in complete Freund's Adjuvant (CFA). On day 10 after immunization, mice were challenged intrathecally with $\mathrm{W}$, and weight courses were monitored daily as percentage of initial body weight (A, $n=5$ mice per group). On day 4 after infection, CNS infiltrating mononuclear cells were isolated. (B) Absolute numbers of CNS infiltrating $\mathrm{CD}^{+}$and $\mathrm{CD}^{+} \mathrm{T}$ cells. Horizontal bars indicate means (Student's $t$ test; $\mathrm{n} \geq 5$ per group). (C) CNS derived T cells were analyzed as to their specificity to the W MHC class I restricted epitope B8R by multimer staining and to their IL-17 and IFN-y cytokine status by intracellular cytokine staining in the $\mathrm{CD}^{+} \mathrm{CD} 8^{+} \mathrm{CTL}$ and $\mathrm{CD}^{+}{ }^{+} \mathrm{CD} 4^{+}$T helper cell compartment, respectively. Numbers indicate percentages of cells in the depicted gates or quadrants; representative out of more than 5 independent experiments). 
was responsible for the failure to clear intracerebral $\mathrm{VV}$ infection.

In order to define potential molecular mechanisms of $\mathrm{T}$ helper cell mediated host protection in intracerebral viral infection, we screened the expression profile of highly purified $\mathrm{CD}_{4}^{+}$effector $\mathrm{T}$ cells isolated from the CNS of VV challenged wild type vs $\alpha 4$ CKO mice for molecules directly involved in virus defense (Figure 7A). $\mathrm{CD}_{4}^{+}$effector T cells expressed Tnf, Grzmb, and Fasl irrespective of whether they were derived from the Th1 biased inflammatory infiltrate of wild type mice or from the Th17 biased inflammatory milieu of $\alpha 4$ CKO mice. In contrast, the expression of perforin-1 (Prf1) was markedly reduced in $\alpha 4$-integrin deficient as compared with wild type $\mathrm{T}$ helper cells. In order to correlate lack of Prf1 expression with the Th17 transcriptional program, we purified $\mathrm{CD}^{+} \mathrm{CD} 4^{+} \mathrm{CD} 44^{-}{ }^{-}$oxp $3^{-}$naïve $\mathrm{T}$ cells from Foxp3gfp.KI mice and stimulated them without exogenous cytokines (Th0) or differentiated them into Th1 cells or Th17 cells (Figure 7B). Consistent with our in vivo data, we found a significant reduction in Prf1 mRNA and protein in Th17 as compared with Th1 and Th0 cells. Notably, protein expression of Prf1 was only seen at late time points (Figure 7B). Since expression of Prf1 has been reported to depend on the expression of the transcription factor eomesodermin (Eomes) [26], we measured RNA levels of Eomes in $\mathrm{CD}_{4}{ }^{+} \mathrm{T}$ cells isolated from brains of $\mathrm{VV}$ infected wild type and $\alpha 4$ CKO mice. Consistent with the low expression of Prf1 in Th17 cells, Eomes mRNA levels were reduced in $\mathrm{CD}^{+} \mathrm{T}$ cells isolated from $\alpha 4$ CKO mice as compared with wild type controls (Figure 7C). To formally validate whether reduced Eomes expression in Th17 cells accounted for diminished Prf1 expression as compared with Th0 and Th1 cells, we polarized Th17 cells in vitro and overexpressed Eomes by retroviral transduction (Figure 7D). FACS sorted transduced $\left(\mathrm{GFP}^{+}\right)$Th17 cells expressed abundant levels of Eomes as compared with control vector proving effective transduction; concomitantly, Prf1 RNA was significantly increased in Eomes transduced Th17 cells. These data suggested that the failure of Th17 cells to express Prf1 was due to reduced Eomes expression.

In order to explore the importance of $\mathrm{CD} 4^{+} \mathrm{T}$ cell derived Prf1 for successful host defense in CNS virus infection in vivo, we immunized Prf1 deficient mice $\left(\mathrm{Prfl}^{-1-}\right)$ with MVA/CFA and established viral encephalitis in $\mathrm{CD}^{+} \mathrm{T}$ cell depleted animals by intrathecal infection with VV (Figure 8). While wild type mice recovered from i.th. VV challenge, Prf1 deficient mice succumbed to viral encephalitis. Numbers and fractions of CNS infiltrating immune cells were comparable between groups (data not shown) indicating that antigen specific priming in the peripheral immune compartment and establishment of inflammatory infiltrates within the CNS were not impaired in $\operatorname{Prfl}^{-/-}$mice. Moreover, wild type mice that were vaccinated with MVA and then depleted of $\mathrm{CD}^{+} \mathrm{T}$ cells in addition to $\mathrm{CD} 8^{+} \mathrm{T}$ cells succumbed to intrathecal challenge with VV although they had similar fractions of NK cells and NK T cells in the CNS as their $\mathrm{CD}_{4}^{+} \mathrm{T}$ cell replete counterparts (Additional file 3: Figure S3) suggesting that alternative sources of Prf1 other than $\mathrm{CD}^{+} \mathrm{T}$ cells were insufficient to provide protection in this model. Taken together, these data demonstrated that Prf1 expression was indispensable for effector $\mathrm{T}$ helper cell mediated control of intrathecal VV infection.

\section{Discussion}

In this study, we tested the concept that host defense against viral infections of the CNS requires distinct $\mathrm{T}$ helper cell subsets. We show that access inhibition to the CNS of selected $\mathrm{T}$ helper cell subsets by integrin targeted interventions results in the failure of host defense. Intrathecal infection with vaccinia virus (VV) was controlled in vaccinated mice when $\mathrm{CD} 4^{+}$and $\mathrm{CD} 8^{+} \mathrm{T}$ cells had access to the CNS compartment. Blockade of $\alpha 4$-integrins by neutralizing antibodies or $\mathrm{T}$ cell conditional disruption of $\alpha 4$-integrin expression did not prevent CTLs and Th17 cells from entering the CNS parenchyma while Th1 cells were blocked from migrating into the CNS. When $\mathrm{CD}^{+}$CTLs were depleted, host defense against intrathecal VV infection was still maintained as long as efficient Th1 like responses were operational within the CNS. In contrast, Th17 cells alone failed to rescue individuals from CNS infection despite a strong inflammatory response. Perforin-1 expression by $\mathrm{T}$ helper cells was required for clearance of intrathecal VV infection and Th17 cells failed to eliminate VV in the CNS due to lack of Eomes dependent Prf1 expression.

Adaptive cellular immune responses are necessary for the clearance of systemic $\mathrm{VV}$ infection. $\mathrm{CD}^{+} \mathrm{T}$ cells recognize epitopes from early antigens of $\mathrm{VV}$ but robust $\mathrm{CD} 4^{+} \mathrm{T}$ cell responses are also required for direct and indirect antiviral effects [27-30]. Niche restricted or organ specific infection may afford specific effector functions. For example, VV skin infection is contained and cleared by a temporally and spatially organized interaction of $\mathrm{Ly}_{6 \mathrm{G}}{ }^{+}$innate immune cells and $\mathrm{CD}^{+}$CTLs [22]. In the ovaries, clearance of VV correlates with the number of effector memory CTLs that are present in the ovaries of VV immunized mice before challenge with the virus [31]. Here, we established an intrathecal infection model with VV and used this system as an in vivo surrogate to correlate the access of distinct $\mathrm{T}$ helper cell subsets with successful host defense. Intrathecal infection of naive wild type C57BL/6 mice with VV was lethal because adaptive antiviral immune responses did not develop upon i.th. infection alone although innate immune 

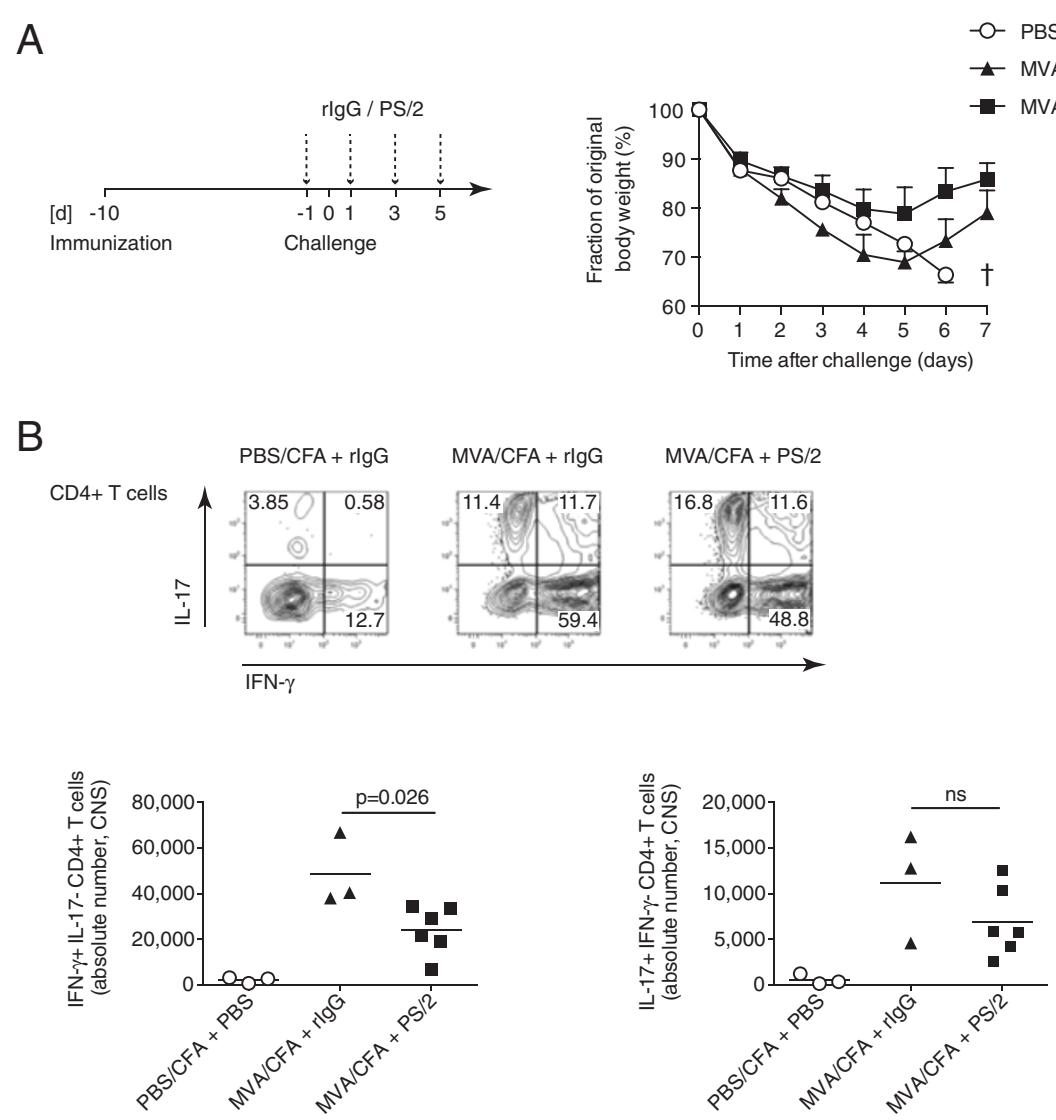

C
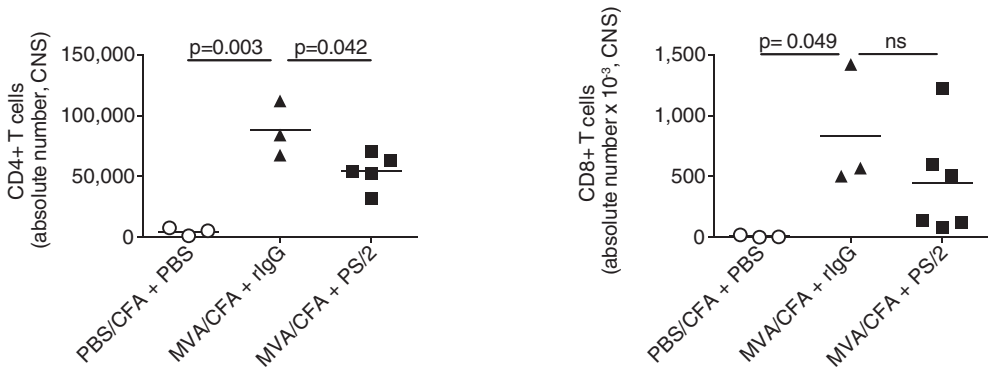

Figure 4 Antibody mediated blockade of integrin a 4 prevents entry of Th1, but not Th17 cells or CD8 ${ }^{+} \mathrm{T}$ cells into the CNS. Wild type mice were sham immunized (PBS/CFA) or immunized with MVA/CFA followed by intrathecal W challenge on day 10 after immunization. Control IgG or antibodies to integrin a4 (PS/2) were administered every other day starting one day prior to W challenge. (A) Weight courses of W challenged animals ( $n=5$ per group). (B, C) On day 4 after infection, CNS infiltrating mononuclear cells were isolated and the absolute number of $\mathrm{CD}^{+} \mathrm{T}$ helper cells and $\mathrm{CD} 8^{+} \mathrm{CTL}$ as well as the cytokine phenotype of $\mathrm{CD} 4^{+} \mathrm{T}$ helper cells from the CNS were assessed based on intracellular staining for IFN- $\gamma$ and IL-17. (B; numbers indicate percentages of CD4 ${ }^{+} T$ cells in each quadrant; representative out of 5 independent experiments. The absolute numbers of T cells were compared by Student's t test, $n \geq 3$ ).

cells and in particular $\mathrm{CD} 11 \mathrm{~b}^{+} \mathrm{CD} 45^{\text {high }}$ monocytic cells were recruited to the infected CNS. Active immunization of mice with MVA in CFA prior to i.th. VV challenge protected the animals from lethal encephalitis. Protection was independent of neutralizing antibodies. However, access of VV specific Th1 cells into the CNS compartment was necessary and sufficient for host protection.
Migration of effector cells into the CNS is mediated by chemokine receptors and integrins. Several cytolytic and non-cytolytic viral infection models of the CNS were used to investigate principles of immune cell recruitment into the CNS. Depending on the viral agent, immune cell recruitment into the CNS cleared the pathogen or in addition, caused immunopathogenic tissue damage. CCR5 and CXCR3 were identified to be 


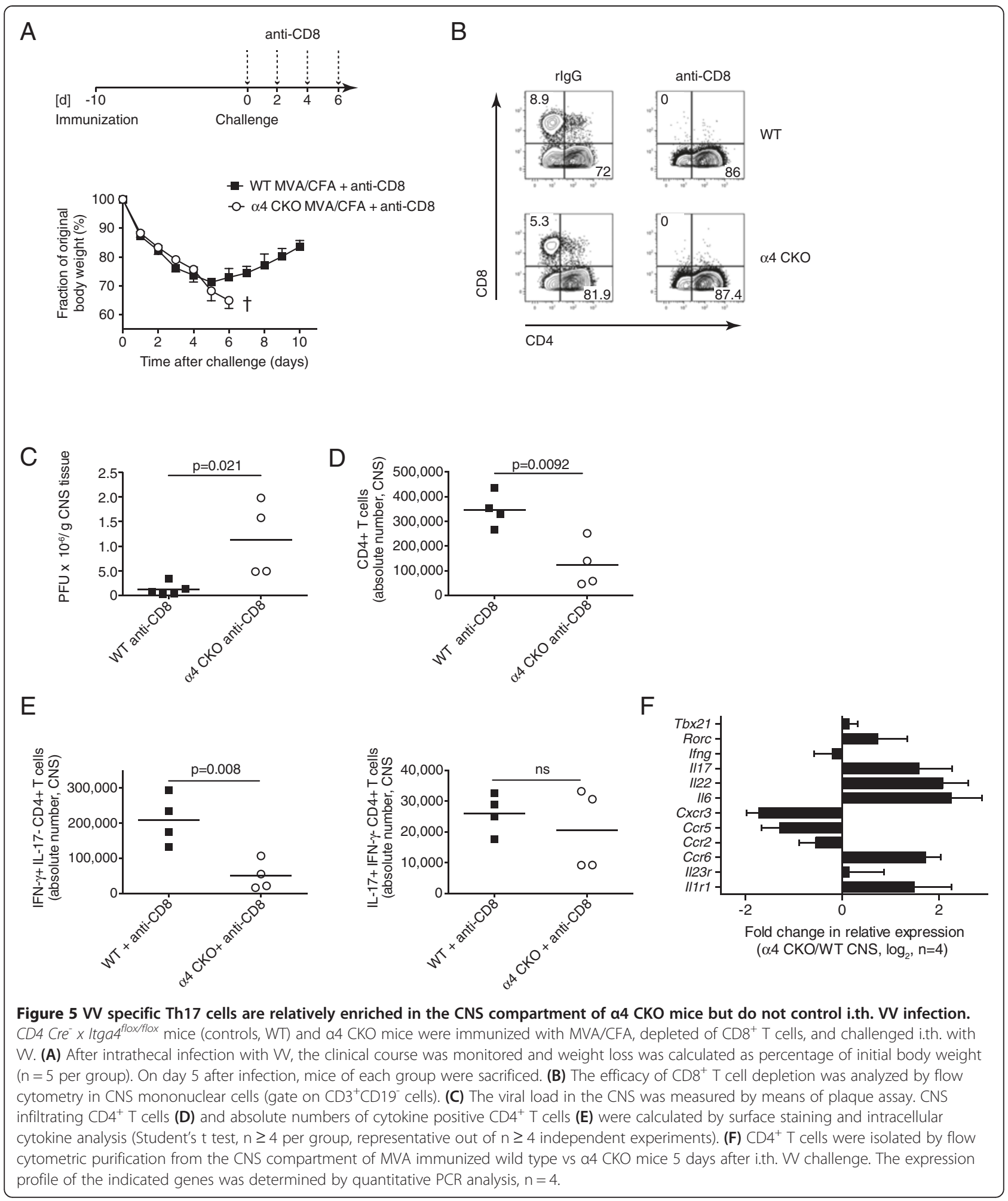

important for immune cell recruitment into the CNS in west nile or MHV and LCMV infection, respectively [32-35]. Chemotaxis of immune cells must be complemented by integrin mediated interaction with endothelial cells for the transmigration of immune cells across the blood brain barrier [36]. Early work suggested that accumulation of antigen specific T cells in the CNS compartment of sindbis virus infected animals is mediated by 

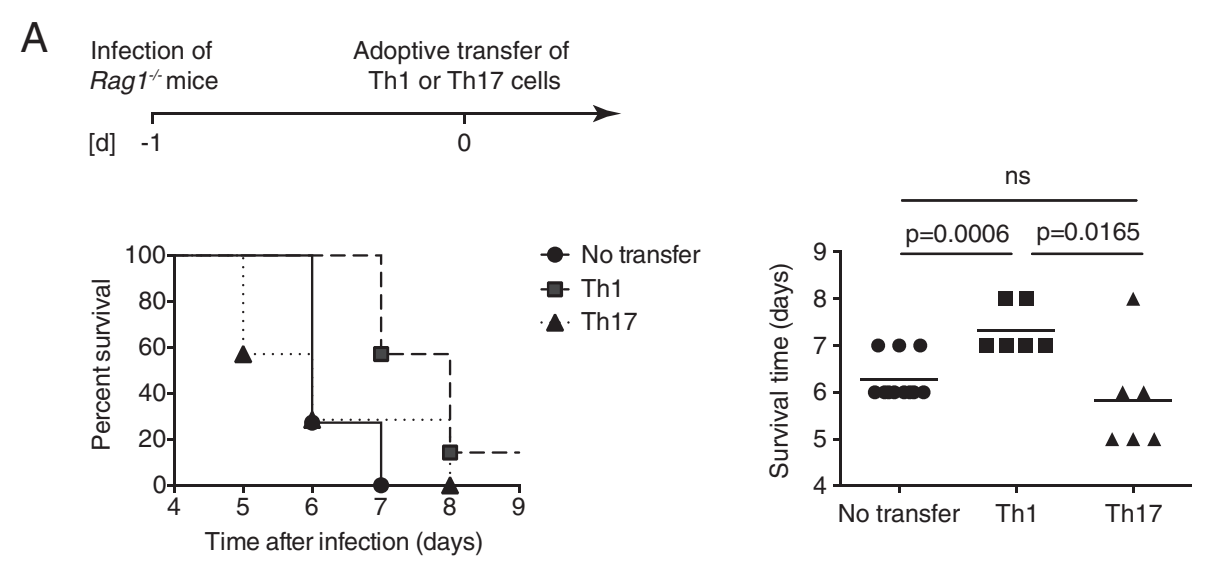

B
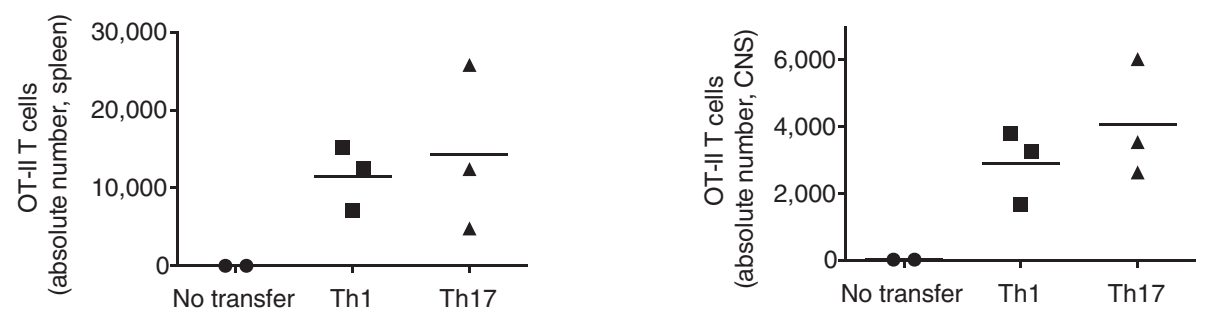

Figure 6 Adoptive transfer of antigen specific Th1 cells but not Th17 cells promotes survival after intrathecal virus infection. Naïve $C D 4^{+} C D 25$ CD44- T cells from OT-II Ova323-339 specific TCR transgenic mice were polarized under Th1 or Th17 conditions in vitro. On day four of differentiation, activated T cells were transferred into Rag $1^{\%}$ mice, which had been infected with a recombinant W expressing ovalbumin (W-Ova) one day earlier. (A) Kaplan-Meier curves of survival (left) and statistical evaluation of time to death (right) are shown. Horizontal bars in the right plot indicate mean survival time in days (ANOVA, $n \geq 5$ per group). (B) Mice were sacrificed on day 6 after transfer and absolute numbers of adoptively transferred $\mathrm{CD}^{+} \mathrm{CD}^{+} \mathrm{T}$ cells in spleens and CNS were assessed (means are indicated by horizontal bars, $\mathrm{n}=3$ per group).

engagement of LFA-1 but not VLA-4 [37]. Using genetic tools, we have recently shown that distinct $\mathrm{T}$ helper cell subsets use distinct integrins to access the CNS compartment in autoimmune inflammation. The entry of Th17 cells into the subarachnoid space most likely requires CCR6 and LFA-1 but is independent of VLA-4 $[4,38]$. In fact, Th17 cells express low levels of $\alpha 4-$ integrins since TGF- $\beta$, which is required for Th17 cell commitment $[17,39,40]$, inhibits the expression of $\alpha 4$ integrins [41]. Interestingly, antigen specific $\mathrm{CD}^{+}$ CTLs also migrated into the CNS independently of $\alpha 4$ integrins (both in $\alpha 4$-integrin antibody blockade and $\mathrm{T}$ cell conditional genetic disruption of Itga4). This is consistent with the observation that $\mathrm{CD}^{+} \mathrm{T}$ cell are preferentially reduced in CSF of natalizumab treated patients as compared with $\mathrm{CD}^{+} \mathrm{T}$ cells resulting in the reversion of the $\mathrm{CSF} C D 4^{+} / \mathrm{CD} 8^{+}$ratio [23]. Although one report suggested that $\mathrm{CD} 8^{+} \mathrm{T}$ cell influx into the CNS was prevented by a blocking antibody to $\alpha 4$-integrins in an intracerebral corona virus infection model, it is unlikely that the recruitment of antigen specific CTLs was assessed by Ifergan et al. since their model did not allow for active priming and activation of adaptive $\mathrm{T}$ cell responses in the systemic lymphoid compartment prior to intracerebral challenge [42]. In contrast to Th17 cells, VLA-4 expression is indispensable and non-redundant for the capacity of antigen experienced Th1 cells to infiltrate into the subarachnoid space and the CNS compartment. Here, we provide evidence that MHC class II positive infected phagocytic cells in the CNS need to be cleared by Th1 cells in order to rescue mice from lethal encephalitis. Thus, MVA-immune $\mathrm{T}$ cell conditional $\alpha 4 \mathrm{KO}$ mice succumbed to intrathecal VV challenge because they failed to recruit Th1 cells into the CNS despite regular Th17 cell accumulation.

Antigen specific $\mathrm{CD} 4^{+} \mathrm{T}$ cells communicated with virus infected macrophages within the CNS parenchyma and only eliminated the infected cells when they were sufficient in perforin-1 expression. In ectromelia infection, a natural mouse pox infection, perforin-1 expression by $\mathrm{CD}^{+} \mathrm{T}$ cells is required to clear the pathogen, and $\mathrm{CD} 4^{+} \mathrm{T}$ cell mediated killing of hematopoietic MHC class II expressing infected target cells occurs in the draining lymph nodes, the liver, and the spleen [28]. Direct cytotoxic effects of antigen specific $\mathrm{CD} 4^{+} \mathrm{T}$ cells were also reported in systemic VV infection [43]. In our 


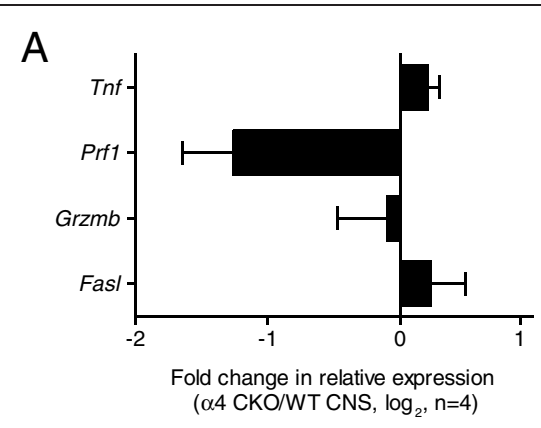

B

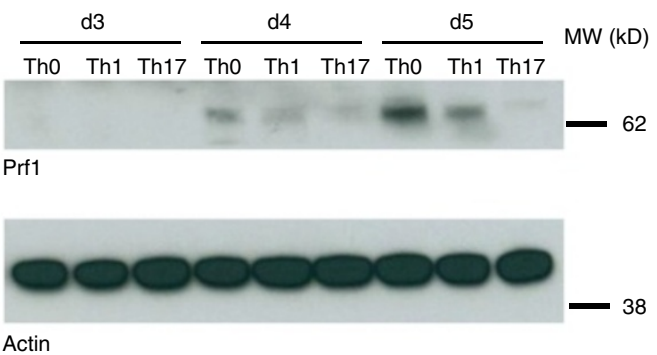

C

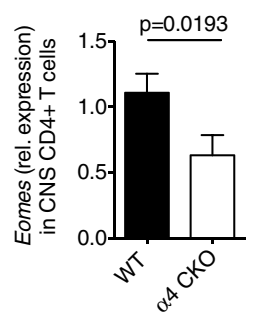

D

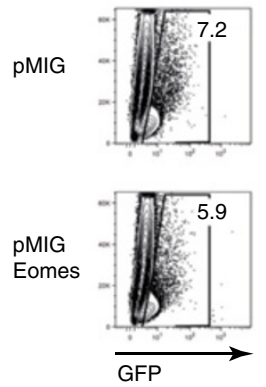

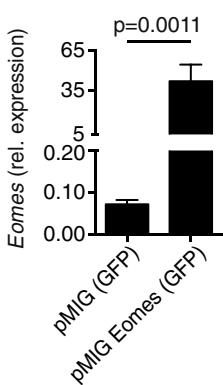

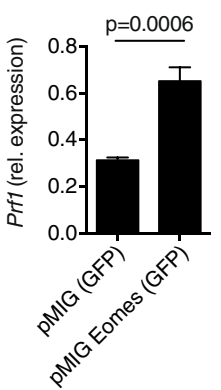

Figure 7 Th17 cells fail to control VV encephalitis due to lack of Prf1 expression. (A) $C D 3^{+} C D 4^{+} T$ cells were highly purified by FACS sorting from the CNS of MVA/CFA immunized wild type or a4 CKO mice on day 4 after intrathecal infection. Fold change in relative expression of the indicated genes in a4 deficient vs. wild type control $C D 4^{+} T$ cells (log scale, means $+S D, n=4$ ). (B) Flow cytometrically purified naïve $\mathrm{CD}^{+} \mathrm{CD}^{+}{ }^{+} \mathrm{CD} 44^{-}$Foxp3 $3^{-} \mathrm{T}$ cells were stimulated without exogenous cytokines (Th0) or differentiated into Th1 cells (IL-12+anti-IL-4), or Th17 cells (TGF- $\beta+$ IL-6). Levels of Prf1 RNA expression were measured by quantitative RT-PCR (left in B, means + SD, Student's $t$ test, $n=4$ ). Time course of Prf1 protein expression was determined by Western Blot in Th0, Th1, and Th17 cells from day 3 to day 5 of culture (right in B). (C) RNA levels of Eomes were measured in wild type and a4 integrin deficient T cells isolated from the CNS of W infected mice (means $+S D, n=4)$. (D) Naïve T cells were differentiated into Th17 cells in vitro and transduced retrovirally with a control vector (pMIG) or an Eomes GFP vector (pMIG Eomes). GFP ${ }^{+}$cells were purified by flow cytometry and RNA levels of Eomes and Prf1 were measured in control transduced Th17 cells vs Th17 cells that ectopically expressed Eomes (means $+\mathrm{SD}, \mathrm{n}=4$ ).
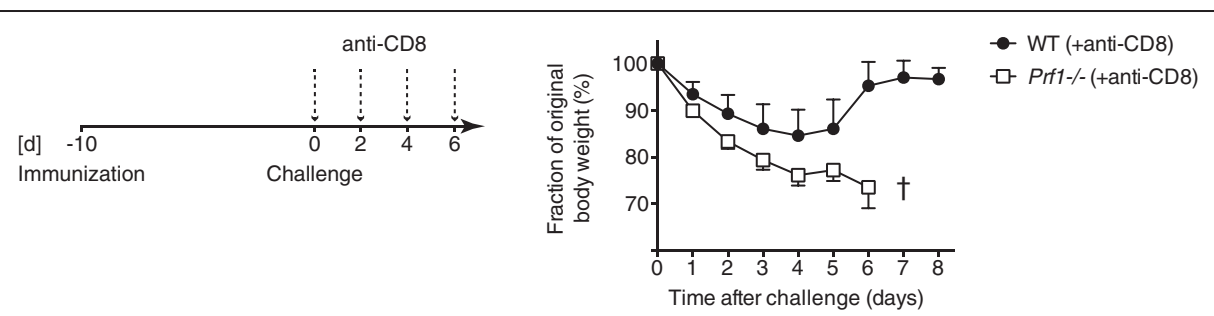

Figure $8 \mathrm{Prf1}^{-/-}$mice succumb to VV encephalitis. Wild type and $\mathrm{Prf}^{-1-}$ mice were immunized with MVA/CFA and continuously depleted of $C D 8^{+} T$ cells after intrathecal $W$ challenge. Weight courses of infected animals ( $n=5$ per group). 
model, $\mathrm{T}$ cell conditional $\alpha 4$-integrin deficient mice behaved like perforin-1 deficient animals and succumbed to infection because perforin-1 expressing Th1 cells did not reach the CNS compartment in the absence of VLA4. Like in EAE, the cytokine phenotype of $\mathrm{T}$ helper cells that entered into the CNS compartment in the absence of $\alpha 4$-integrin showed a Th17 profile [4]. Th17 cells did not express perforin-1. Initial Th17 cell commitment is sensitive to IL-2 and high IL-2 concentrations inhibit Th17 differentiation [44]. In contrast, IL-2 promotes the expression of granzyme $\mathrm{B}$ and perforin-1 and boosts cytotoxic capacity of $\mathrm{CD}^{+} \mathrm{T}$ cells [45]. While the transcriptional control of granzyme $\mathrm{B}$ and perforin-1 has in part been investigated in $\mathrm{CD}^{+} \mathrm{T}$ cells [46], we found that perforin-1 expression in Th1 cells is associated with Eomes and overexpression of Eomes in Th17 cells partially reconstituted perforin-1 expression. Similar observations have been reported for Th2 cells that per se also lack perforin-1 [26], which correlates with their low cytotoxic efficacy. However, lack of perforin-1 expression in Th17 cells may not be the only mechanism to impair their antiviral capacity. For example, Th17 cells are able to mount a protective response in primary lung infection with influenza in IL-10 KO mice suggesting that Th17 cells are particularly susceptible to IL-10 mediated suppression [47]. In addition, induction of prosurvival factors by Th17 cells may contribute to viral persistence in the CNS in Theiler's virus infection [48]. Conversely, it is possible that in some anatomical niches, Th17 cells may contribute to protective antiviral immune responses, e.g. by effective IL-17 mediated recruitment of neutrophils in lung infection [49]. Also, IL-21, which is produced by Th17 cells, might have a role in the modulation of primary and recall CTL responses by increasing their proliferation and reducing their sensitivity to exhaustion [50]. However, overall it is a more common scenario that antiviral Th17 responses fail to clear viral pathogens but rather drive deleterious immunopathology in the skin [51], in the cornea [52], and also in the CNS.

We have shown that blockade or genetic lack of $\alpha 4$ integrins on $\mathrm{T}$ cells selectively modulated the access of $\mathrm{T}$ helper cell subsets to the CNS. Preferential limitation of Th1 trafficking jeopardized host defense against intrathecal VV infection. Nevertheless, our experimental system has several limitations: First, i.th. inoculation of VV does not represent a natural route of CNS infection. Yet, immunization with virus antigens in CFA provides an efficient way to generate both an antigen specific Th1 and Th17 response in the secondary lymphoid tissue and to study their trafficking and effector functions upon i.th. challenge with a well characterized pathogen. Second, i.th. VV infection results in an acute encephalomyelitis, which causes rapid decay and death of infected animals; in contrast, JC virus induced PML is due to insufficient control of a latent virus infection of oligodendrocytes. However, the intracerebral anti-JC virus $\mathrm{CD} 4^{+} \mathrm{T}$ cell response contributes substantially to JCV control because efficient clearance of JC virus from the CNS after immune reconstitution by wash-out of natalizumab in MS patients with PML is associated with the re-occurrence of Th1 cells in the CNS [53].

\section{Conclusions}

Our experimental model provides a mechanistic explanation for insufficient virus control under conditions of altered $\mathrm{T}$ cell migration. Our data raise the concern that treatment of humans with compounds like natalizumab that interfere with $\mathrm{T}$ cell trafficking not only by quantitatively reducing the migration of T cells into the CNS but also by selectively targeting distinct $\mathrm{T}$ cell subsets may evoke serious deficiencies in cellular immune responses at privileged anatomical sites like the CNS. As a result, primary infections or unexpected reactivations of latent viruses may be facilitated.

\section{Supporting data}

The data sets supporting the results of this article are included within the article and its additional files.

\section{Additional files}

\begin{abstract}
Additional file 1: Figure S1. a4 integrin deficiency in T cells does not alter priming or humoral responses against $W$ after immunization. (A) CD4 Cre- $\times$ Itgaf $4^{\text {flox/flox }}$ mice (wild type control (WT)) or CD4 Cre ${ }^{+} \times$Itga $^{\text {flox/flox }}$ mice (a4 CKO) were immunized with MVA/CFA. On day 10 after immunization, splenocytes were isolated and restimulated with an I-Ab restricted peptide epitope mix of $W$. Fractions of antigen specific cytokine producing $\mathrm{CD}^{+} \mathrm{T}$ cells were determined by intracellular CD40L (CD154) and cytokine staining. Numbers in the gates represent means $\pm S D, n=3$. (B) Specific serum neutralization capacity of sera collected on day 10 after immunization of wild type or a4 CKO mice vaccinated with PBS/CFA or MVA/CFA (specific neutralization capacity in percent of maximum, means $+S D, n=5)$
\end{abstract}

Additional file 2: Figure S2. IFN- $\gamma$ expression in $\mathrm{CD}^{+} \mathrm{T}$ cells is not required for virus control in the CNS. (A) Wild type mice were immunized with MVA/CFA and challenged intrathecally with W on day 10. Starting one day before $W$ challenge, neutralizing antibodies to IFN- $\gamma$ (or contro lgG) and depleting antibodies to CD8 were applied alternatingly every other day. Weight courses of infected animals were measured every day after infection and depicted relative to initial body weight ( $n=5$ per group). (B) Expression of MHC class II on CNS microglial cells (gating on CD11 $b^{\text {int }}$ CD45 ${ }^{\text {int }}$, upper panel) was measured on day 6 after infection using surface staining and flow cytometric analysis. Numbers indicate percentages. Histogram: black line: MHC class II expression on migroglia from control lgG treated mice, grey/shaded line: MHC class II expression on microglia from anti-IFN- $\gamma$ treated mice. The numbers in the histogram represent mean fluorescence intensities. Representative out of 3 independent experiments.

Additional file 3: Figure S3. $C D 4^{+} T$ cells mediate protection against $W$ encephalitis in the absence of $\mathrm{CD}^{+} \mathrm{T}$ cells. Wild type mice immunized with MVA/CFA were challenged i.th. with W and depleted of $\mathrm{CD}^{+} \mathrm{T}$ cells. Concomitantly, animals were treated with isotype control or depleting antibodies to CD4 every other day. (A) Percentage of surviving mice are depicted in Kaplan-Meier curves of survival ( $n=6$ per group). (B) CNS infiltrating mononuclear cells were analyzed by flow cytometry. Upper panel: Staining for CD4 and CD8 in the $\mathrm{CD}^{+} \mathrm{T}$ cell gate. Lower panel: Staining for CD3 and Nk1.1 in the CD4 gate (representative out of 4 independent experiments). 


\section{Competing interests}

The authors declare that they have no competing interests.

\section{Authors' contributions}

TK, VR and AM designed the study and wrote the manuscript. VR and AM contributed equally, carried out all the experiments and where herein supported by GG, FP, and SH. DHB provided fluorescence-labeled MHC class I $\mathrm{H}-2 \mathrm{~K}^{\mathrm{b}} / \mathrm{BBR}_{20-27}$ (TSYKFESV) multimers. Histological analyses were carried out with the support of MH's group. GG, DHB, MH, BH and ID gave conceptional input and revised the manuscript. All authors read and approved the final manuscript.

\section{Acknowledgments}

TK is recipient of a Heisenberg award by the Deutsche

Forschungsgemeinschaft (DFG, KO2964/3-2). This work was supported by SyNergy (Munich Cluster of Systems Neurology) and by other grants from the DFG (SFB1054/B06, TR128/A06, A07) as well as by intramural funding of the Klinikum rechts der Isar (KKF B11-11). MH was supported by the Helmholtz foundation.

\section{Author details}

${ }^{1}$ Klinikum rechts der Isar, Department of Neurology, Technische Universität München, Ismaninger Str. 22, 81675 Munich, Germany. ${ }^{2}$ Institute of Virology, Helmholtz Zentrum München, Technische Universität München, Schneckenburger Str. 8, 81675 Munich, Germany. ${ }^{3}$ Howard Hughes Medical Institute and Immunology Program, Memorial Sloan-Kettering Cancer Center, New York, NY 10065, USA. ${ }^{4}$ Institute for Medical Microbiology, Immunology, and Hygiene, Technische Universität München, Trogerstr. 30, 81675 Munich, Germany. ${ }^{5}$ Munich Cluster for Systems Neurology (SyNergy), Munich, Germany. ${ }^{6}$ Institute for Virology, Düsseldorf University Hospital, Heinrich-Heine-University, Universitätsstr. 1, 40225 Düsseldorf, Germany.

Received: 25 February 2014 Accepted: 26 February 2014 Published: 7 March 2014

\section{References}

1. Domingues HS, Mues M, Lassmann H, Wekerle H, Krishnamoorthy G: Functional and pathogenic differences of Th1 and th 17 cells in experimental autoimmune encephalomyelitis. PLoS One 2010, 5:e15531. doi:10.1371/journal.pone.0015531.

2. Yednock TA, Cannon C, Fritz LC, Sanchez-Madrid F, Steinman L, Karin N: Prevention of experimental autoimmune encephalomyelitis by antibodies against alpha 4 beta 1 integrin. Nature 1992, 356:63-66. doi:10.1038/356063a0.

3. Polman $\mathrm{CH}, \mathrm{O}^{\prime}$ Connor PW, Havrdova E, Hutchinson M, Kappos L, Miller DH, Phillips JT, Lublin FD, Giovannoni G, Wajgt A, Toal M, Lynn F, Panzara MA, Sandrock AW, AFFIRM Investigators: A randomized, placebo-controlled trial of natalizumab for relapsing multiple sclerosis. N Engl J Med 2006, 354:899-910. doi:10.1056/NEJMoa044397.

4. Rothhammer V, Heink S, Petermann F, Srivastava R, Claussen MC, Hemmer B, Korn T: Th17 lymphocytes traffic to the central nervous system independently of a4 integrin expression during EAE. J Exp Med 2011, 208:2465-2476. doi:10.1084/jem.20110434.

5. Ransohoff RM, Engelhardt B: The anatomical and cellular basis of immune surveillance in the central nervous system. Nat Rev Immunol 2012, 12:623-635. doi: 10.1038/nri3265.

6. Gebhardt T, Whitney PG, Zaid A, Mackay LK, Brooks AG, Heath WR, Carbone FR, Mueller SN: Different patterns of peripheral migration by memory CD4+ and CD8+ T cells. Nature 2011, 477:216-219. doi:10.1038/nature10339.

7. Lebwohl M, Tyring SK, Hamilton TK, Toth D, Glazer S, Tawfik NH, Walicke P, Dummer W, Wang X, Garovoy MR, Pariser D, Efalizumab Study Group: A novel targeted T-cell modulator, efalizumab, for plaque psoriasis. N Engl J Med 2003, 349:2004-2013. doi: 10.1056/NEJMoa030002.

8. Kappos L, Radue E-W, O'Connor P, Polman C, Hohlfeld R, Calabresi P, Selmaj K, Agoropoulou C, Leyk M, Zhang-Auberson L, Burtin P, FREEDOMS Study Group: A placebo-controlled trial of oral fingolimod in relapsing multiple sclerosis. N Engl J Med 2010, 362:387-401. doi: 10.1056/NEJMoa0909494.

9. Selmaj K, Li DK, Hartung H-P, Hemmer B, Kappos L, Freedman MS, Stüve O, Rieckmann P, Montalban X, Ziemssen T, Auberson LZ, Pohlmann H, Mercier F, Dahlke F, Wallström E: Siponimod for patients with relapsing-remitting multiple sclerosis (BOLD): an adaptive, dose-ranging, randomised, phase 2 study. Lancet Neurol 2013, 12:756-767. doi:10.1016/S1474-4422(13)70102-9.
10. Miller DH, Weber T, Grove R, Wardell C, Horrigan J, Graff O, Atkinson G, Dua P, Yousry $T$, Macmanus $D$, Montalban X: Firategrast for relapsing remitting multiple sclerosis: a phase 2, randomised, double-blind, placebo-controlled trial. Lancet Neurol 2012, 11:131-139. doi:10.1016/S1474-4422(11)70299-X.

11. Hueber W, Patel DD, Dryja T, Wright AM, Koroleva I, Bruin G, Antoni C, Draelos Z, Gold MH, Psoriasis Study Group, Durez P, Tak PP, Gomez-Reino JJ, Rheumatoid Arthritis Study Group, Foster CS, Kim RY, Samson CM, Falk NS, Chu DS, Callanan D, Nguyen QD, Uveitis Study Group, Rose K, Haider A, Di Padova F: Effects of AIN457, a fully human antibody to interleukin-17A, on psoriasis, rheumatoid arthritis, and uveitis. Sci Transl Med 2010, 2:52ra72. doi:10.1126/scitransImed.3001107.

12. Leonardi C, Matheson R, Zachariae C, Cameron G, Li L, Edson-Heredia E, Braun D, Banerjee S: Anti-interleukin-17 monoclonal antibody ixekizumab in chronic plaque psoriasis. N Engl J Med 2012, 366:1190-1199. doi:10.1056/NEJMoa1109997.

13. Yazici Y, Curtis JR, Ince A, Baraf H, Malamet RL, Teng LL, Kavanaugh A: Efficacy of tocilizumab in patients with moderate to severe active rheumatoid arthritis and a previous inadequate response to disease-modifying antirheumatic drugs: the ROSE study. Ann Rheum Dis 2012, 71:198-205. doi:10.1136/ard.2010.148700.

14. Major EO: Progressive multifocal leukoencephalopathy in patients on immunomodulatory therapies. Annu Rev Med 2010, 61:35-47. doi:10.1146/annurev.med.080708.082655.

15. Sette A, Moutaftsi M, Moyron-Quiroz J, McCausland MM, Davies DH, Johnston RJ, Peters B, Rafii-El-Idrissi Benhnia M, Hoffmann J, Su H-P, Singh K, Garboczi DN, Head S, Grey H, Felgner PL, Crotty S: Selective CD4+ T cell help for antibody responses to a large viral pathogen: deterministic linkage of specificities. Immunity 2008, 28:847-858. doi:10.1016/j.immuni.2008.04.018.

16. Moutaftsi M, Bui H-H, Peters B, Sidney J, Salek-Ardakani S, Oseroff C, Pasquetto V, Crotty S, Croft M, Lefkowitz E, Grey H, Sette A: Vaccinia virusspecific CD4+ T cell responses target a set of antigens largely distinct from those targeted by CD8+ T cell responses. J Immunol 2012, 178:6814-6820.

17. Bettelli E, Carrier Y, Gao W, Korn T, Strom TB, Oukka M, Weiner HL, Kuchroo VK: Reciprocal developmental pathways for the generation of pathogenic effector TH17 and regulatory T cells. Nature 2006, 441:235-238. doi:10.1038/nature04753.

18. Korn T, Reddy J, Gao W, Bettelli E, Awasthi A, Petersen TR, Bäckström BT, Sobel RA, Wucherpfennig KW, Strom TB, Oukka M, Kuchroo VK: Myelin-specific regulatory T cells accumulate in the CNS but fail to control autoimmune inflammation. Nat Med 2007, 13:423-431. doi:10.1038/nm1564.

19. Scott LM, Priestley GV, Papayannopoulou T: Deletion of alpha4 integrins from adult hematopoietic cells reveals roles in homeostasis, regeneration, and homing. Mol Cell Biol 2003, 23:9349-9360.

20. Koedel U, Rupprecht T, Angele B, Heesemann J, Wagner H, Pfister H-W, Kirschning CJ: MyD88 is required for mounting a robust host immune response to Streptococcus pneumoniae in the CNS. Brain 2004, 127:1437-1445. doi:10.1093/brain/awh171.

21. Staib C, Drexler I, Sutter G: Construction and isolation of recombinant MVA. Methods Mol Biol 2004, 269:77-100. doi:10.1385/1-59259-789-0:077.

22. Hickman HD, Reynoso GV, Ngudiankama BF, Rubin EJ, Magadán JG, Cush SS, Gibbs J, Molon B, Bronte V, Bennink JR, Yewdell JW: Anatomically restricted synergistic antiviral activities of innate and adaptive immune cells in the skin. Cell Host Microbe 2013, 13:155-168. doi:10.1016/j.chom.2013.01.004.

23. Stüve O, Marra CM, Bar-Or A, Niino M, Cravens PD, Cepok S, Frohman EM, Phillips JT, Arendt G, Jerome KR, Cook L, Grand'Maison F, Hemmer B, Monson NL, Racke MK: Altered CD4+/CD8+ T-cell ratios in cerebrospinal fluid of natalizumab-treated patients with multiple sclerosis. Arch Neurol 2006, 63:1383-1387. doi:10.1001/archneur.63.10.1383.

24. Kowarik MC, Pellkofer HL, Cepok S, Korn T, Kümpfel T, Buck D, Hohlfeld R, Berthele A, Hemmer B: Differential effects of fingolimod (FTY720) on immune cells in the CSF and blood of patients with MS. Neurology 2011, 76:1214-1221. doi:10.1212/WNL.0b013e3182143564.

25. Jelcic I, Aly L, Binder TMC, Jelcic I, Bofill-Mas S, Planas R, Demina V, Eiermann TH, Weber T, Girones R, Sospedra M, Martin R: T cell epitope mapping of JC polyoma virus-encoded proteome reveals reduced $T$ cell responses in HLA-DRB1*04:01+ donors. J Virol 2013, 87:3393-3408. doi:10.1128/JVI.02803-12.

26. Eshima K, Chiba S, Suzuki H, Kokubo K, Kobayashi H, lizuka M, Iwabuchi K, Shinohara N: Ectopic expression of a T-box transcription factor, eomesodermin, renders CD4(+) Th cells cytotoxic by activating both 
perforin- and FasL-pathways. Immunol Lett 2012, 144:7-15. doi:10.1016/j.imlet.2012.02.013.

27. Jellison ER, Kim S-K, Welsh RM: Cutting edge: MHC class II-restricted killing in vivo during viral infection. J Immunol 2005, 174:614-618.

28. Fang M, Siciliano NA, Hersperger AR, Roscoe F, Hu A, Ma X, Shamsedeen AR, Eisenlohr LC, Sigal L: Perforin-dependent CD4+ T-cell cytotoxicity contributes to control a murine poxvirus infection. Proc Natl Acad Sci U S A 2012, 109:9983-9988. doi:10.1073/pnas.1202143109/-/DCSupplemental.

29. Sun JC, Bevan MJ: Defective CD8 T cell memory following acute infection without CD4 T cell help. Science 2003, 300:339-342. doi:10.1126/science.1083317.

30. Xu R, Johnson AJ, Liggitt D, Bevan MJ: Cellular and humoral immunity against vaccinia virus infection of mice. J Immunol 2004, 172:6265-6271.

31. Bachmann MF, Wolint $P$, Schwarz K, Oxenius A: Recall proliferation potential of memory CD8+ T cells and antiviral protection. J Immunol 2005, 175:4677-4685.

32. Glass WG, Lim JK, Cholera R, Pletnev AG, Gao J-L, Murphy PM: Chemokine receptor CCR5 promotes leukocyte trafficking to the brain and survival in West Nile virus infection. J Exp Med 2005, 202:1087-1098. doi:10.1084/jem.20042530.

33. Glass WG, Liu MT, Kuziel WA, Lane TE: Reduced macrophage infiltration and demyelination in mice lacking the chemokine receptor CCR5 following infection with a neurotropic coronavirus. Virology 2001, 288:8-17. doi:10.1006/viro.2001.1050.

34. Nansen A, Christensen JP, Andreasen S $\varnothing$, Bartholdy C, Christensen JE, Thomsen AR: The role of CC chemokine receptor 5 in antiviral immunity. Blood 2002, 99:1237-1245.

35. Christensen JE, Nansen A, Moos T, Lu B, Gerard C, Christensen JP, Thomsen AR: Efficient T-cell surveillance of the CNS requires expression of the CXC chemokine receptor 3. J Neurosci 2004, 24:4849-4858. doi:10.1523/JNEUROSCI.0123-04.2004

36. Engelhardt B, Ransohoff RM: Capture, crawl, cross: the T cell code to breach the blood-brain barriers. Trends Immunol 2012, 33:579-589. doi:10.1016/j.it.2012.07.004.

37. Irani DN, Griffin DE: Regulation of lymphocyte homing into the brain during viral encephalitis at various stages of infection. J Immunol 1996, 156:3850-3857.

38. Reboldi A, Coisne C, Baumjohann D, Benvenuto F, Bottinelli D, Lira S, Uccelli A, Lanzavecchia A, Engelhardt B, Sallusto F: C-C chemokine receptor 6-regulated entry of $\mathrm{TH}-17$ cells into the $\mathrm{CNS}$ through the choroid plexus is required for the initiation of EAE. Nat Immuno/ 2009, 10:514-523. doi:10.1038/ni.1716

39. Veldhoen M, Hocking RJ, Atkins CJ, Locksley RM, Stockinger B: TGFbeta in the context of an inflammatory cytokine milieu supports de novo differentiation of IL-17-producing T cells. Immunity 2006, 24:179-189. doi:10.1016/j.immuni.2006.01.001.

40. Mangan PR, Harrington LE, O'quinn DB, Helms WS, Bullard DC, Elson CO, Hatton RD, Wahl SM, Schoeb TR, Weaver CT: Transforming growth factor-beta induces development of the $\mathrm{T}(\mathrm{H}) 17$ lineage. Nature 2006, 441:231-234. doi:10.1038/nature04754.

41. Zhang $N$, Bevan MJ: Transforming growth factor- $\beta$ signaling controls the formation and maintenance of gut-resident memory $T$ cells by regulating migration and retention. Immunity 2013, 39:687-696. doi:10.1016/j.immuni.2013.08.019.

42. Ifergan I, Kebir H, Alvarez JI, Marceau G, Bernard M, Bourbonnière L, Poirier J, Duquette $P$, Talbot PJ, Arbour N, Prat A: Central nervous system recruitment of effector memory CD8+ T lymphocytes during neuroinflammation is dependent on a4 integrin. Brain 2011, 134:3560-3577. doi:10.1093/brain/ awr268.

43. Oxenius A, Bachmann MF, Zinkernagel RM, Hengartner H: Virus-specific major MHC class II-restricted TCR-transgenic mice: effects on humoral and cellular immune responses after viral infection. Eur J Immunol 1998, 28:390-400.

44. Laurence A, Tato CM, Davidson TS, Kanno Y, Chen Z, Yao Z, Blank RB, Meylan F, Siegel R, Hennighausen L, Shevach EM, O'Shea JJ: Interleukin-2 signaling via STAT5 constrains T helper 17 cell generation. Immunity 2007, 26:371-381. doi:10.1016/j.immuni.2007.02.009.

45. Brown DM, Kamperschroer C, Dilzer AM, Roberts DM, Swain SL: IL-2 and antigen dose differentially regulate perforin- and FasL-mediated cytolytic activity in antigen specific CD4+ T cells. Cell Immunol 2009, 257:69-79. doi:10.1016/j.cellimm.2009.03.002.
46. Pipkin ME, Sacks JA, Cruz-Guilloty F, Lichtenheld MG, Bevan MJ, Rao A: Interleukin-2 and inflammation induce distinct transcriptional programs that promote the differentiation of effector cytolytic T cells. Immunity 2010, 32:79-90. doi:10.1016/j.immuni.2009.11.012.

47. McKinstry KK, Strutt TM, Buck A, Curtis JD, Dibble JP, Huston G, Tighe M, Hamada H, Sell S, Dutton RW, Swain SL: IL-10 deficiency unleashes an influenza-specific Th17 response and enhances survival against high-dose challenge. J Immunol 2009, 182:7353-7363. doi:10.4049/jimmunol.0900657.

48. Hou W, Kang HS, Kim BS: Th17 cells enhance viral persistence and inhibit T cell cytotoxicity in a model of chronic virus infection. J Exp Med 2009, 206:313-328. doi:10.1084/jem.20082030.

49. Tate MD, Deng Y-M, Jones JE, Anderson GP, Brooks AG, Reading PC: Neutrophils ameliorate lung injury and the development of severe disease during influenza infection. J Immunol 2009, 183:7441-7450. doi:10.4049/jimmunol.0902497.

50. Barker BR, Gladstone MN, Gillard GO, Panas MW, Letvin NL: Critical role for IL-21 in both primary and memory anti-viral CD8+ T-cell responses. Eur J Immunol 2010, 40:3085-3096. doi:10.1002/eji.200939939.

51. Oyoshi MK, Elkhal A, Kumar L, Scott JE, Koduru S, He R, Leung DYM, Howell MD, Oettgen HC, Murphy GF, Geha RS: Vaccinia virus inoculation in sites of allergic skin inflammation elicits a vigorous cutaneous IL-17 response. Proc Natl Acad Sci U S A 2009, 106:14954-14959. doi:10.1073/pnas.0904021106.

52. Suryawanshi A, Veiga-Parga T, Rajasagi NK, Reddy PBJ, Sehrawat S, Sharma S, Rouse BT: Role of IL-17 and Th17 cells in herpes simplex virus-induced corneal immunopathology. J Immuno/ 2011, 187:1919-1930. doi:10.4049/jimmunol.1100736.

53. Aly L, Yousef S, Schippling S, Jelcic I, Breiden P, Matschke J, Schulz R, Bofill-Mas S, Jones L, Demina V, Linnebank M, Ogg G, Girones R, Weber T, Sospedra M, Martin R: Central role of JC virus-specific CD4+ lymphocytes in progressive multi-focal leucoencephalopathy-immune reconstitution inflammatory syndrome. Brain 2011, 134:2687-2702. doi:10.1093/brain/awr206.

doi:10.1186/2051-5960-2-27

Cite this article as: Rothhammer et al:: a4-integrins control viral meningoencephalitis through differential recruitment of $\mathrm{T}$ helper cell subsets. Acta Neuropathologica Communications 2014 2:27.

\section{Submit your next manuscript to BioMed Central and take full advantage of:}

- Convenient online submission

- Thorough peer review

- No space constraints or color figure charges

- Immediate publication on acceptance

- Inclusion in PubMed, CAS, Scopus and Google Scholar

- Research which is freely available for redistribution

Submit your manuscript at www.biomedcentral.com/submit
C) Biomed Central 